\title{
Main geological and mining factors affecting ground cracks induced by underground coal mining in Shanxi Province, China
}

\author{
Xugang Lian ${ }^{1} \cdot$ Haifeng $\mathrm{Hu}^{1} \cdot \mathrm{TaO}_{\mathrm{Li}^{2}} \cdot$ Dongsheng $\mathrm{Hu}^{2}$
}

Received: 29 June 2019/Revised: 27 January 2020/Accepted: 10 March 2020/Published online: 20 March 2020

(C) The Author(s) 2020

\begin{abstract}
As one of the largest coal-rich provinces in China, Shanxi has extensive underground coal-mining operations. These operations have caused numerous ground cracks and substantial environmental damage. To study the main geological and mining factors influencing mining-related ground cracks in Shanxi, a detailed investigation was conducted on 13 mining-induced surface cracks in Shanxi. Based on the results, the degrees of damage at the study sites were empirically classified into serious, moderate, and minor, and the influential geological and mining factors (e.g., proportions of loess and sandstone in the mining depth, ratio of rock thickness to mining thickness, and ground slope) were discussed. According to the analysis results, three factors (proportion of loess, ratio of rock thickness to mining thickness, and ground slope) play a decisive role in ground cracks and can be respectively considered as the critical material, mechanical, and geometric conditions for the occurrence of mining surface disasters. Together, these three factors have a strong influence on the occurrence of serious discontinuous ground deformation. The results can be applied to help prevent and control ground damage caused by coal mining. The findings also provide a direct reference for predicting and eliminating hidden ground hazards in mining areas.
\end{abstract}

Keywords Loess layer · Main geological and mining factors · Ground cracks · Ground slope · Underground coal mining

\section{Introduction}

As the main component of China's energy structure, coal resources play an important role in the national economy. Shanxi Province possesses large coal reserves characterized by shallow burial depth and good quality. According to estimates, the coal-bearing strata in the province occupy an area of $61,050 \mathrm{~km}^{2}$, accounting for $39.1 \%$ of the total area of the province. Of the 118 administrative units (i.e., counties, cities, and districts) in Shanxi Province, 94 have coal resources, accounting for $80 \%$ of the total area of the

Xugang Lian

lianxugang@tyut.edu.cn

1 School of Mining Engineering, Taiyuan University of Technology, Taiyuan 030024, Shanxi, China

2 Geological Survey Department, Yangquan Coal Industry (Group) Co., Ltd., Yangquan 045000, Shanxi, China province. In 2015, the coal reserves in Shanxi Province totaled 270.901 billion tons, accounting for $17.3 \%$ of China's reserves, and the production volume was 967 million tons (Shanxi Province Statistics Bureau 20142018). The exploitation of underground coal resources in Shanxi has resulted in serious surface disasters. As shown in Fig. 1, the operation of mines in six large coal fields in Shanxi Province produced large steps and cracks in the ground, endangering human lives. To explore the geological and mining factors influencing these serious surface disasters caused by underground mining, we analyzed the conditions surrounding mining-related surface disasters in Shanxi Province and determined the causes of the ground cracks.

Currently, the main methods for monitoring natural disasters are based on satellites, aerial drones, and wireless sensor networks. Many scholars monitor and track earthquakes, tsunamis, floods, and other disasters using satellite remote sensing technology (Iwasaki et al. 2012; Kwak 


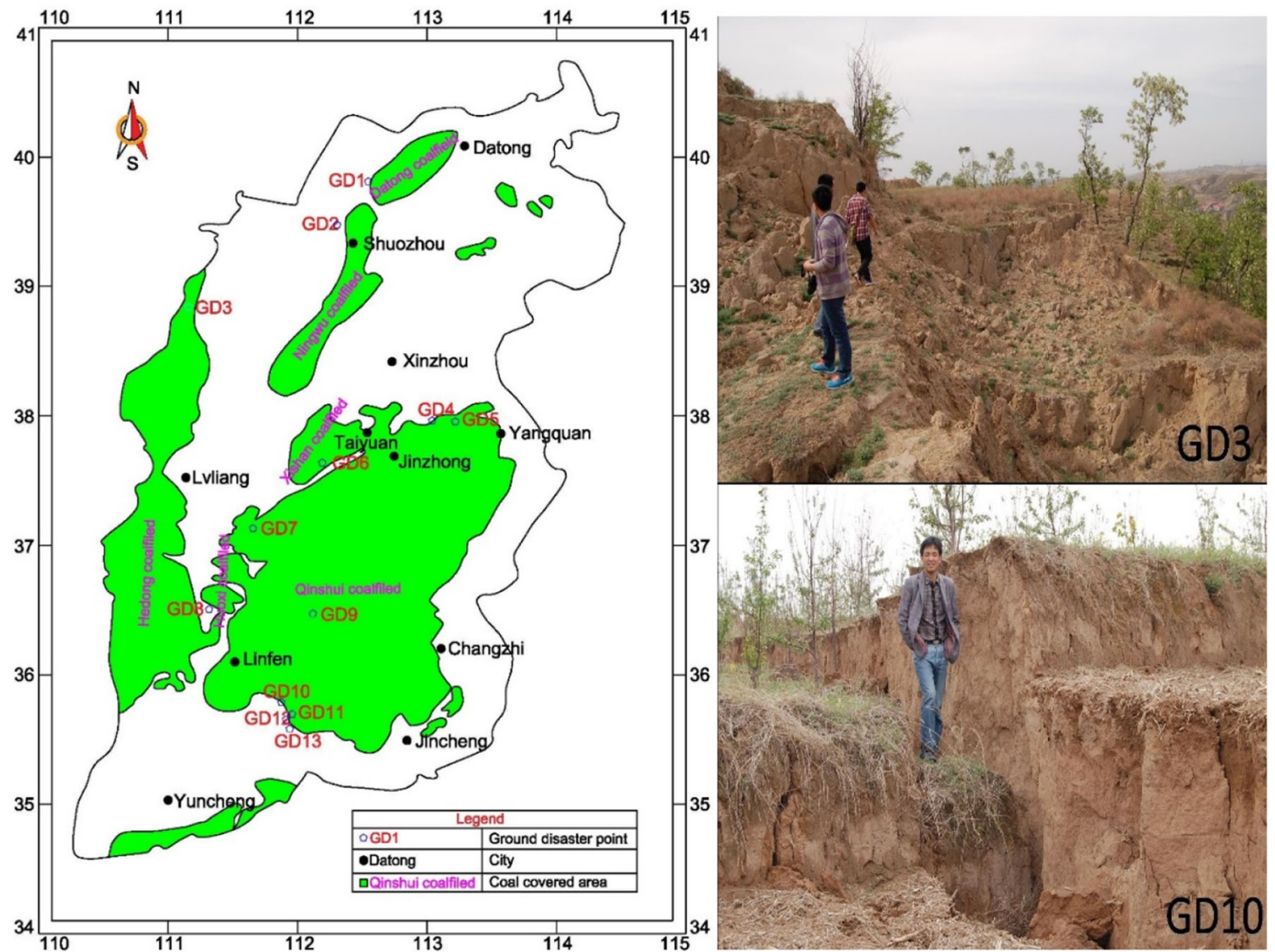

Fig. 1 Map showing the six large coal fields in Shanxi Province (left) and images showing two sites of ground disasters (right)

2017; Singh et al. 2013). To improve the image resolution and more clearly analyze ground disasters, drones are used to monitor and manage disasters such as earthquakes, floods, and fires (Adams and Friedland 2011; Kim et al. 2016; Yuan et al. 2015). In recent years, wireless sensor networks have been used for the real-time monitoring and prediction of ground disasters such as floods and landslides (Kussul et al. 2014; Lule and Bulega 2015; Taenaka et al. 2012). Combinations of drones and wireless sensor networks have also been used to monitor and manage ground disasters (Erdelj et al. 2017; Kurz et al. 2012).

The main ground disasters caused by coal mining include surface subsidence, landslides, cracks, steps, and collapse pits. In recent years, the main methods used to monitor large-scale mining subsidence disasters have been remote sensing (e.g., differential interferometry) and optical remote sensing (e.g., the pixel displacement method) approaches. Differential InSAR has been widely used to monitor land subsidence in mining areas around the world, including Shenmu (Chengsheng et al. 2010) and Huainan (Dong et al. 2013) in China; Silesia (Graniczny et al. 2015; Mirek 2012; Przyłucka et al. 2015) in Poland; New South Wales (Ng et al. 2010) in Australia; and the Franco-German border (Samsonov et al. 2013). A series of improved
InSAR algorithms have been applied to monitor mining subsidence, including TS-SAR (Zhang et al. 2015), ATSSAR (Du et al. 2018), SBAS (Grzovic and Ghulam 2015), PS-SAR (Wegmuller et al. 2010), SqueeSAR (Ishwar and Kumar 2017), and interferogram stacking (Zhang et al. 2010). Although the problem of monitoring three-dimensional movement has largely been solved, the monitoring range for settlement remains small. The pixel displacement method can be applied to increase the range of remote sensing monitoring of settlement; this method has been applied to monitor large-scale subsidence in mining areas, resulting in a range of $3.5-4.5 \mathrm{~m}$ and an accuracy of 0.15-0.2 m (Huang et al. 2016; Zhao et al. 2013).

Compared to remote sensing monitoring, traditional monitoring based on ground observation is more time consuming and expensive; however, traditional monitoring can record the state of damage in detail and provide accurate information on surface movement during mining subsidence. Field investigation and traditional surveying were used to analyze the sudden subsidence caused by shallow mining in the Datong mining area (Cui et al. 2014). By setting up observation stations on the surface of the working face, researchers studied surface subsidence associated with the high-intensity mining of the buried coal 
seam (Junjie et al. 2016). Ground investigation and statistical analysis were applied to evaluate the degree of ground damage caused by mining in a village in Huainan, Anhui Province (Lian and Dai 2016). Three-dimensional laser scanning was used to measure the failure status of the mining surface in Gaoyang Mine, Shanxi Province, and to analyze the failure state of the mining high-pressure line tower (Lian and Hu 2017). Wang et al. (2019) examined ground subsidence caused by mining in Australia, India, and China and proposed the method of filling mining to slow surface subsidence. Field investigation and statistical analysis were employed to evaluate discontinuous surface deformation caused by high-intensity mining in the Shendong mining area and mine-sand bulge disaster (Yan et al. 2018).

These studies indicate that natural disasters have been systematically monitored from three aspects: space, sky and wireless sensor networks. Furthermore, land subsidence caused by coal mining has been systematically investigated using remote sensing. However, the assessment of ground steps, cracks, and other forms of damage caused by underground mining still depends on ground monitoring methods, including field investigation, statistical analysis, and conventional measurement. Therefore, this study used field survey data along with the geological mining conditions to analyze the surface damage caused by underground mining in Shanxi Province.

\section{Investigation of ground cracks}

\subsection{Investigation targets}

We investigated 13 ground cracks caused by underground coal mining in Shanxi Province. Figure 1 shows the locations of the study sites. The specific location, size, mining depth, mining date, backfill collapse, and water filling condition of the extracted area and roadway were determined for each site by information collection and investigation. The geological conditions mainly included the position, shape, size, depth, and extension direction of the ground collapse pit; the relation of the ground step or crack to the goaf; the geologic structure; the mining boundary; and the advancing direction.

\subsection{Investigation tools}

The following tools were used to conduct the field investigation: (1) Steel tape gauge: To quantitatively describe crack size, the crack width and step height were measured using a steel tape gauge. (2) Camera: Cameras were used to record images of the cracks in the field. (3) Global positioning system (GPS): GPS was used to locate the position of fracture formation and determine the distribution of cracks.

\section{Investigation results}

Based on the investigation of 13 ground cracks caused by underground coal mining in Shanxi Province, the ground damage grade along with the geological and mining conditions of the disaster sites are listed in Table 1.

The characteristics listed in Table 1 are defined as follows:

(1) Mining depth: Depth of coal seam burial.

(2) Loess thickness and geologic map: Thickness of the surface loess in the strata overlying the coal seam and the ground geologic condition of each crack site.

(3) Subsidence rate: Ratio of maximum ground subsidence to mining thickness.

(4) Maximum damage degree: Maximum width of the ground crack and maximum height of the step.

(5) Ratio of rock to thickness: Ratio of the thickness of the overlying bedrock to the mining thickness.

(6) Proportion of loess layer: Ratio of the thickness of the loess layer to the mining depth.

(7) Proportion of sandstone: Ratio of the total sandstone thickness to the mining depth.

(8) Ground slope: Interval of the surface gradient in the subsidence area $\left(4-5 \mathrm{~km}^{2}\right)$ affected by underground mining.

(9) Classification code of land use: Code according to the land use classification system of the Chinese Academy of Sciences.

(10) Ground damage grade: Since there is no uniform standard for the level of ground damage caused by mining, damage in this study was classified according to the crack width and step size according to the grades defined in Table 2, which are based on empirical data from the land reclamation industry in China.

The data derived from the disaster site investigation are presented in Table 3.

The cracks at GD1 are located at the strike boundary of the working face. The offset distance is $30 \mathrm{~cm}$ at the cement road, and the height of soil uplift under the extrusion is $20 \mathrm{~cm}$. There are six parallel cracks with widths of $3-30 \mathrm{~cm}$, step heights of $4-10 \mathrm{~cm}$, and crack lengths of $39-110 \mathrm{~m}$ at the first cut of the panel.

The cracks at GD2 are located directly above the goaf. The depth of collapse is $4-5 \mathrm{~m}$, and the width of the parallel crack is $3 \mathrm{~cm}$. The collapse area has many step cracks. 
Table 1 Ground damage grade along with the geological and mining conditions of crack sites

\begin{tabular}{|c|c|c|c|c|c|c|c|c|c|c|c|}
\hline \multirow[t]{2}{*}{ No. } & \multirow[t]{2}{*}{$\begin{array}{l}\text { Mining } \\
\text { depth } \\
(\mathrm{m})\end{array}$} & \multirow{2}{*}{$\begin{array}{l}\text { Loess } \\
\text { thickness and } \\
\text { geologic map } \\
\text { (m) }\end{array}$} & \multirow[t]{2}{*}{$\begin{array}{l}\text { Subsidence } \\
\text { rate }\end{array}$} & \multicolumn{2}{|c|}{$\begin{array}{l}\text { Maximum } \\
\text { damage } \\
\text { degree }(\mathrm{cm})\end{array}$} & \multirow[t]{2}{*}{$\begin{array}{l}\text { Ratio of } \\
\text { rock to } \\
\text { thickness }\end{array}$} & \multirow[t]{2}{*}{$\begin{array}{l}\text { Proportion } \\
\text { of loess } \\
\text { layer }(\%)\end{array}$} & \multirow{2}{*}{$\begin{array}{l}\text { Proportion } \\
\text { of } \\
\text { sandstone } \\
(\%)\end{array}$} & \multirow[t]{2}{*}{$\begin{array}{l}\text { Ground } \\
\text { slope } \\
\left({ }^{\circ}\right)\end{array}$} & \multirow[t]{2}{*}{$\begin{array}{l}\text { Classification } \\
\text { code of land } \\
\text { use }\end{array}$} & \multirow[t]{2}{*}{$\begin{array}{l}\text { Ground } \\
\text { damage } \\
\text { level }\end{array}$} \\
\hline & & & & Crack & Step & & & & & & \\
\hline GD1 & 241 & $46(\mathrm{Q}+\mathrm{R}+\mathrm{P})$ & 0.78 & 30 & 10 & 16 & 19 & 53 & $6-15$ & 122 & Moderate \\
\hline GD2 & 180 & $65(\mathrm{Q}+\mathrm{R})$ & 0.77 & 170 & 360 & 12 & 36 & 15 & $15-25$ & 122 & Serious \\
\hline GD3 & 300 & $80(\mathrm{Q})$ & 1.18 & 100 & 300 & 16 & 27 & 9 & $15-25$ & 12133 & Serious \\
\hline GD4 & 300 & $25(\mathrm{Q}+\mathrm{P})$ & 0.4 & 5 & 0 & 110 & 8 & 17 & $2-6$ & 122 & Minor \\
\hline GD5 & 400 & $45(\mathrm{Q}+\mathrm{P})$ & 0.6 & 5 & 0 & 178 & 11 & 7 & $6-15$ & 12123 & Minor \\
\hline GD6 & 270 & $12(P+Q)$ & 0.8 & 70 & 50 & 110 & 4 & 13 & $15-25$ & 3223 & Serious \\
\hline GD7 & 334 & $70(\mathrm{Q})$ & 0.6 & 204 & 212 & 30 & 21 & 7 & $15-25$ & 33123 & Serious \\
\hline GD8 & 190 & $55(\mathrm{Q}+\mathrm{R})$ & 0.7 & 7 & 7 & 75 & 29 & 23 & $15-25$ & 31 & Minor \\
\hline GD9 & 280 & $5(\mathrm{R})$ & 0.6 & 3 & 0 & 196 & 2 & 26 & $6-15$ & 12121 & Minor \\
\hline GD10 & 160 & $130(\mathrm{Q})$ & 0.9 & 90 & 170 & 12 & 81 & 3 & $15-25$ & 3152121 & Serious \\
\hline GD11 & 300 & $13(P+Q)$ & 0.5 & 20 & 10 & 104 & 4 & 16 & $6-15$ & 12252 & Moderate \\
\hline GD12 & 240 & $25(P+Q)$ & 0.6 & 50 & 40 & 119 & 10 & 14 & $15-25$ & 2321 & Serious \\
\hline GD13 & 260 & $50(P+Q)$ & 0.5 & 20 & 20 & 40 & 19 & 38 & $15-25$ & 12121 & Moderate \\
\hline
\end{tabular}

Table 2 Definitions of damage grades based on maximum surface deformation in the subsidence area

\begin{tabular}{|c|c|c|c|c|c|}
\hline \multirow[t]{2}{*}{ Ground damage grade } & \multicolumn{2}{|c|}{ Ground crack parameters } & \multirow[t]{2}{*}{ Horizontal strain $(\mathrm{mm} / \mathrm{m})$} & \multirow[t]{2}{*}{ Tilt $(\mathrm{mm} / \mathrm{m})$} & \multirow[t]{2}{*}{ Production reduction } \\
\hline & Width $(\mathrm{cm})$ & Interval (m) & & & \\
\hline Minor & $1-10$ & $50-100$ & $3-6$ & $3-10$ & $<10 \%$ \\
\hline Moderate & $10-30$ & $30-50$ & $6-10$ & $10-20$ & $10 \%-30 \%$ \\
\hline Serious & $>30$ & $<30$ & $>10$ & $>20$ & $>30 \%$ \\
\hline
\end{tabular}

Table 3 Disaster site field data

\begin{tabular}{llcccc}
\hline No. & Mining depth $(\mathrm{m})$ & Mining thickness $(\mathrm{m})$ & Loess thickness $(\mathrm{m})$ & Subsidence rate & Ground slope $\left(^{\circ}\right)$ \\
\hline GD1 & 241 & 12.0 & 46 & 0.78 & $6-15$ \\
GD2 & 180 & 9.4 & 65 & 0.77 & $6-15$ \\
GD3 & 300 & 14.0 & 80 & 1.18 & 0.4 \\
GD4 & 300 & 2.5 & 25 & 0.6 & $2-6$ \\
GD5 & 400 & 2.0 & 45 & 0.8 & $6-15$ \\
GD6 & 270 & 2.34 & 12 & 0.6 & $6-15$ \\
GD7 & 334 & 8.7 & 70 & 0.7 & $15-25$ \\
GD8 & 190 & 1.8 & 55 & 0.6 & $15-25$ \\
GD9 & 280 & 1.4 & 5 & 0.9 & $6-15$ \\
GD10 & 160 & 2.5 & 130 & 0.5 & $15-25$ \\
GD11 & 300 & 2.75 & 13 & 0.6 & $6-15$ \\
GD12 & 240 & 1.8 & 25 & 0.5 & $6-15$ \\
GD13 & 260 & 5.2 & 50 & 6 \\
\hline
\end{tabular}


The range of subsidence is $27-360 \mathrm{~cm}$, and the crack width ranges from $35-170 \mathrm{~cm}$.

The maximum thickness of the loess at GD3 is $200 \mathrm{~m}$. The collapse area is large and mainly distributed on top of the disturbed slope in the goaf. The crack width ranges from $5-100 \mathrm{~cm}$, and step height ranges from $50-300 \mathrm{~cm}$.

The cracks at GD4 are located directly above the goaf as well as on the edge and along the strike of the goaf. The crack width on cultivated land ranges from $3-5 \mathrm{~cm}$, and crack length ranges from 11-25 $\mathrm{m}$. The visible depth of the cracks is $1-1.5 \mathrm{~m}$, and no steps are seen.

The cracks at GD5 are distributed on the bench terraces on the edge of the goaf with widths of $2-5 \mathrm{~cm}$ and a depth of $2 \mathrm{~m}$. The diameter of the collapse pit ranges from $60-70 \mathrm{~cm}$.

The crack at GD6 is located near the stoppage line of the coal panel. A group of cracks, most of which are connected, is located near the top of the slope. The crack length and width are 10-20 m and 6-70 cm, respectively, and the step height is $30-50 \mathrm{~cm}$.

The cracks at GD7 are located above the coal panel, mainly at the top of the slope. The crack width is $20-204 \mathrm{~cm}$, and the step height is $30-212 \mathrm{~cm}$. In some areas, a rise in the valley floor can be observed.

The cracks at GD8 are mainly distributed on the ground in the village and on the walls above the coal panel. The widths and lengths of the pavement cracks are $2-7 \mathrm{~cm}$ and 2-6 m, respectively. The step height is $4-7 \mathrm{~cm}$. The widths of the wall cracks are $1-6 \mathrm{~cm}$, and the windows are obviously stretched.

The mountains above the goaf are mainly composed of rocks. The horizontal crack at GD9 is caused by the horizontal dislocation of the exposed rock strata. The crack width and length are $2-3 \mathrm{~cm}$ and $2-5 \mathrm{~m}$, respectively. The vertical crack is due to the vertical dislocation of the rock strata; the width and length are $1-15 \mathrm{~cm}$ and $1-2 \mathrm{~m}$, respectively.

The crack at GD10 is located above the coal panel, and the crack direction is vertical to the advancing direction. In the apple orchard, the soil at the crack edge is partially collapsed. The crack width is $10-90 \mathrm{~cm}$, the crack length is $50-150 \mathrm{~m}$, and the step height is $30-170 \mathrm{~cm}$.

Cracks at GD11 appear above the coal panel, mainly distributed in farmland and industrial buildings, with a width of 3-20 cm, a step height of $10 \mathrm{~cm}$, and a length of 2-10 m.

Cracks at GD12 are located at the boundary of the goaf. A relatively large number of cracks with irregular distribution are observed. The uncultivated land is widely distributed; there are large steps and cracks with widths of $5-50 \mathrm{~cm}$, lengths of 5-25 m, and step heights of 5-40 cm.

Cracks at GD13 are located above the goaf; nine cracks with widths of $2-15 \mathrm{~cm}$ and subsidence in the range of
$50-60 \mathrm{~cm}$ are found on the road. The cracks on the cultivated land have widths of $2-20 \mathrm{~cm}$, step heights of $7-20 \mathrm{~cm}$, and lengths of $14-20 \mathrm{~m}$. The crack depth is $1.5-3 \mathrm{~m}$.

\section{Discussion and analysis}

\subsection{Analysis of field data}

The results of the analysis of the field survey data on ground cracks caused by underground coal mining (Tables 1,2 and 3) can be summarized as follows.

(1) Analysis of the data collected from the GD2, GD3, GD7, and GD10 ground cracks indicated that the main factors contributing to serious ground cracks are the proportion of loess layer, ratio of rock to thickness, and ground slope; these factors can respectively be considered as the material (i.e., ratio of loess to mining depth $>20 \%$ ), mechanical (i.e., ratio of bedrock to mining thickness $<30$ ), and geometric (i.e., ground slope $>15^{\circ}$ ) conditions necessary for serious ground damage. While the above three criteria are almost satisfied for site GD1, this site represents an abnormal case in which the overburden contains a large proportion of sandstone, and the degree of surface cracks is low.

Although sites GD6 and GD12 are classified as serious damage, their crack widths and step heights are much smaller than those of the other four sites with this classification. This is related to the classification criteria of ground crack grade. The formation of surface cracks at sites GD6 and GD12 is mainly affected by surface slope and loess layer.

(2) The ratio of rock to thickness was the main factor affecting serious ground cracks rather than the ratio of depth to thickness because of a situation similar to that at site GD10. Given that loess and bedrock are two different media, when the loess is extremely thick and the rock layer is extremely thin, the loess cannot play the role of a rock, and serious ground collapse and cracks occur easily.

(3) At sites GD8 and GD13, the ratio of rock to thickness criteria (mechanical condition) was not met, whereas the other two criteria (material and geometric conditions) were not satisfied. In these cases, serious ground failure did not occur, and the ground cracks were not classified as serious.

(4) When the ratio of rock to thickness and proportion of loess layer criteria were not satisfied, while the ground slope criteria was met (e.g., sites GD9 and GD11), the surface damage was not serious.

(5) When none of the three conditions were satisfied (e.g., sites GD4 and GD5), no serious ground damage occurred. 
The distribution of coal fields in Shanxi Province and the locations of the study sites are presented in Fig. 1. As mentioned above, for the formation of serious ground cracks to occur, the following three criteria must generally be met: (1) material condition criteria (proportion of loess layer $>20 \%$ ); (2) mechanical condition criteria (ratio of rock to thickness $<30$ ); and (3) geometric condition criteria (ground slope $>15^{\circ}$ ). Normally, all three criteria must be satisfied for the ground cracks to reach a serious level. However, when the proportion of sandstone in the overburden is large, serious ground cracks might not be generated even if all the criteria are met. This finding provides basis for ensuring ground safety.

\subsection{Influence of ground slope, land use classification, and ground geological conditions on ground cracks}

The ground slope map of Shanxi Province shown in Fig. 2 visualizes the ground slope of each crack site. Combined with the data in Table 1, the slope can be concluded to play an important role in ground cracks, and terrain with slope

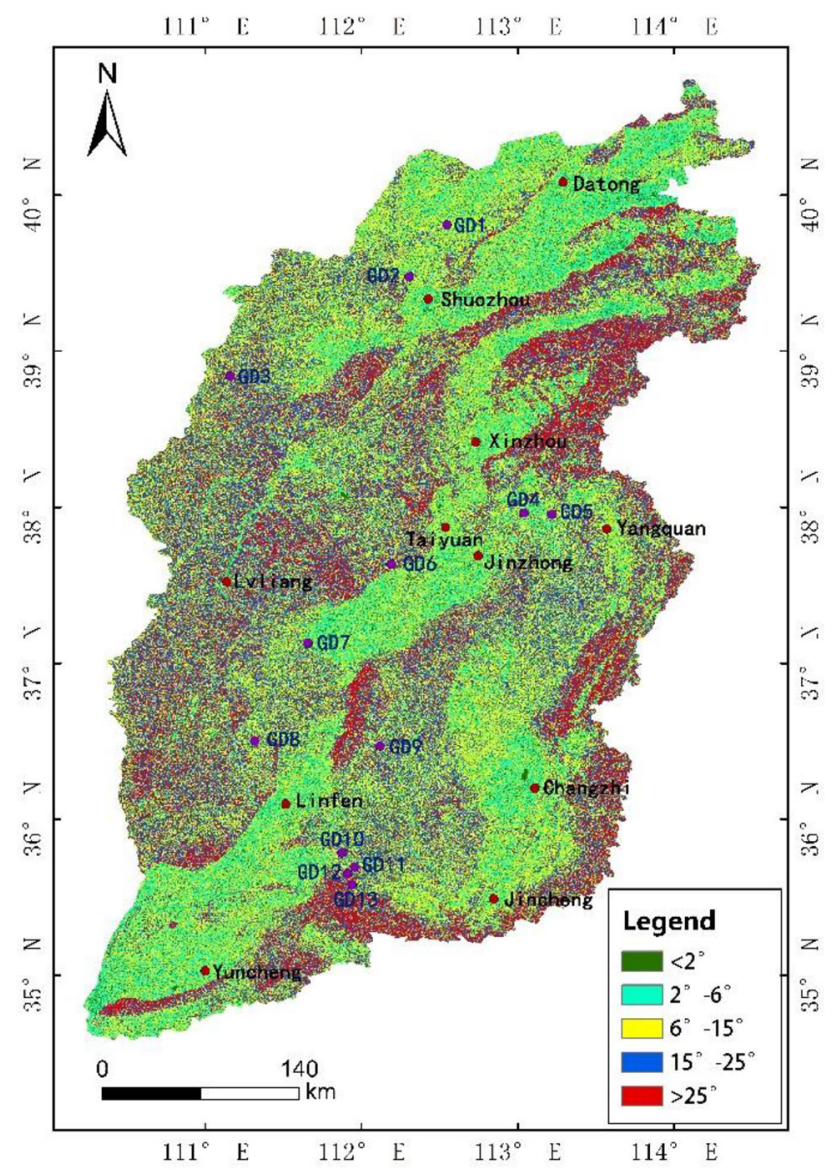

Fig. 2 Locations of ground crack study sites shown on the slope map of Shanxi Province, China $>25^{\circ}$ will generally experience more serious ground damage.

According to the land use classifications of the Chinese Academy of Sciences, the codes for different land uses are as follows: cultivated land $(121=$ mountain dryland, $122=$ hills dryland, 123 = flatlands dryland); forest land $(21=$ forest land, $23=$ open $\quad$ woodland); grassland ( $31=$ high-coverage grassland, $\quad 32=$ medium-coverage grassland, $33=$ low-coverage grassland); and residential land $(52=$ land for rural residential use). The locations of the study sites are overlain on a map of land use classification for Shanxi Province in Fig. 3, and the land use codes for the sites are listed in Table 1 . The crack sites are mainly distributed in cultivated land followed by forest land, grassland, and residential land. No strong correlation was observed between ground damage grade and land use type. Instead, damage was mainly related to protective measures of mining surface structures (e.g., protective coal pillars for residential land).

Figure 4 shows the locations of the study sites on a geologic map of Shanxi Province. In Table 1, the column "loess thickness and geologic map" indicates the thickness

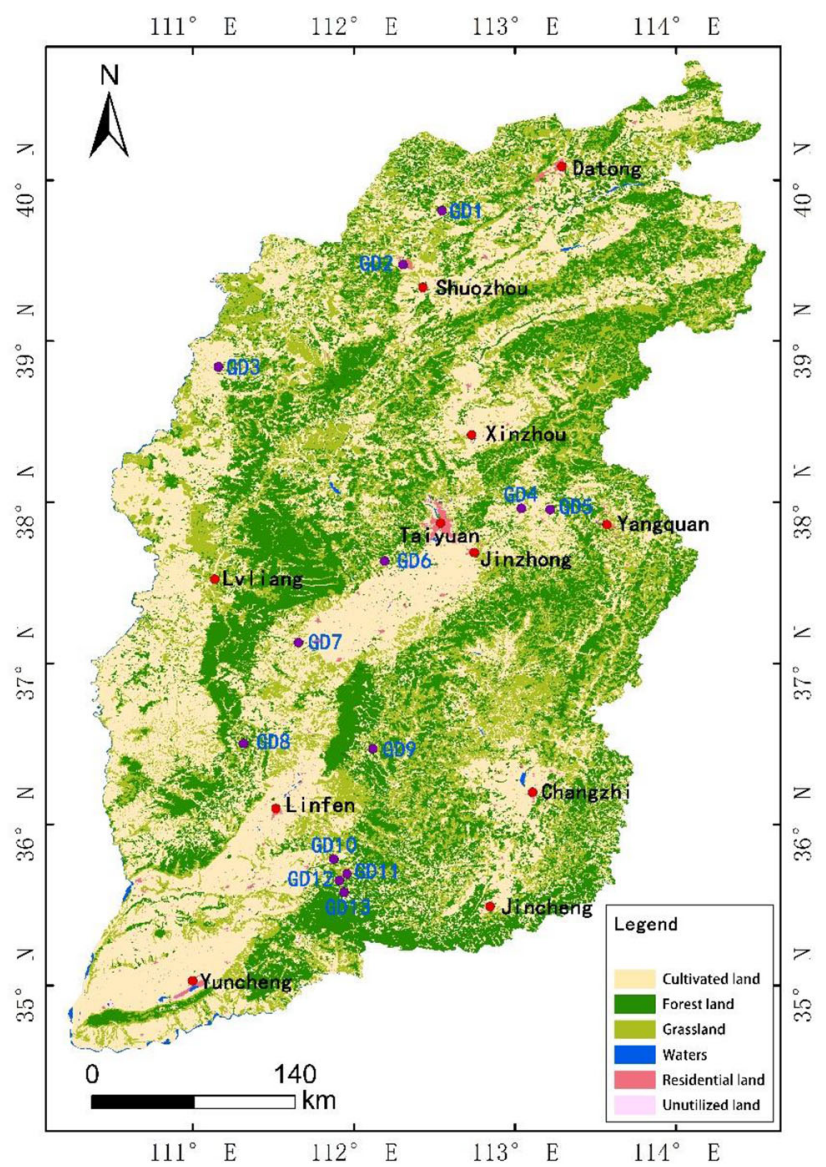

Fig. 3 Locations of ground crack study sites shown on the land use classification map of Shanxi Province, China 


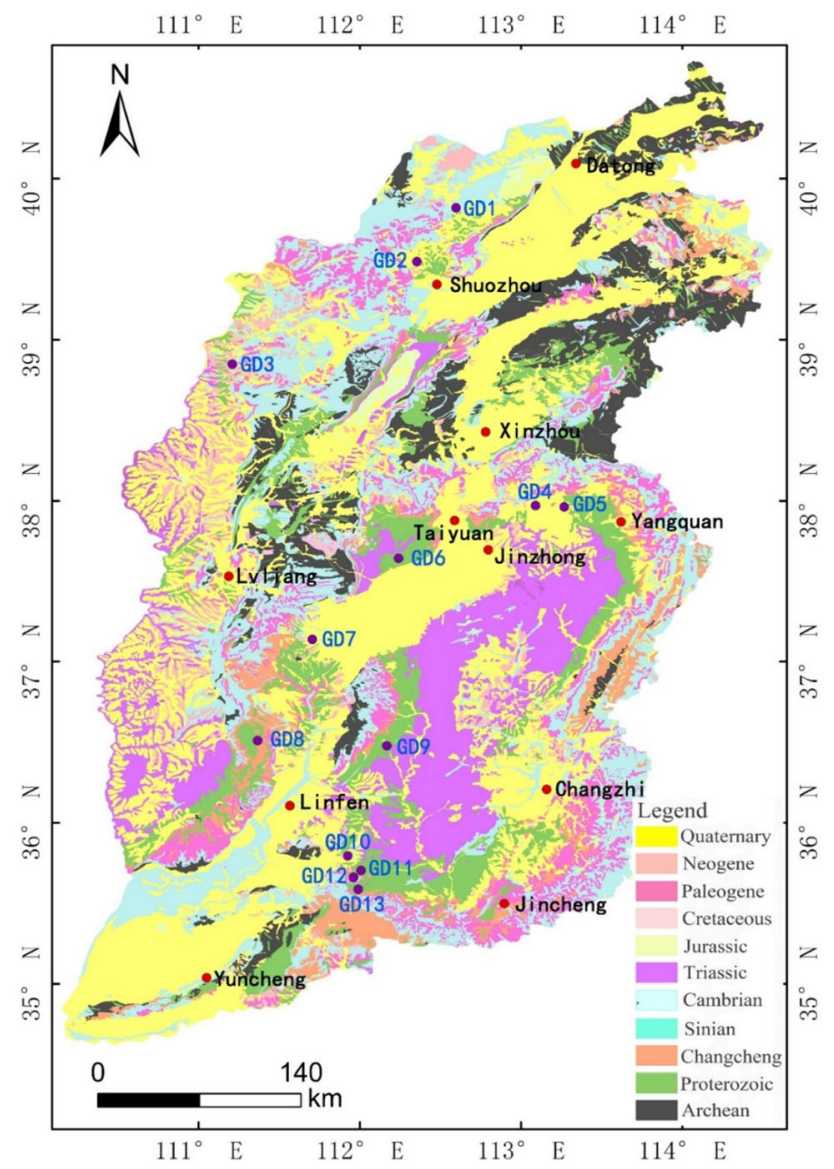

Fig. 4 Locations of ground crack study sites shown on the geologic map of Shanxi Province, China

of loess and the geological condition of the ground at each crack site; Q, R, and P in this column indicate Quaternary, Tertiary, and Permian systems, respectively. The surface of a disaster site can involve one, two, or all three of these strata. Based on Table 1, for sites with serious ground damage, the overlying strata are mainly Quaternary strata, suggesting that Quaternary strata are more susceptible to mining disturbances compared to other formations.

\subsection{Mechanism and classification of crack formation}

Loess and bedrock are two very different media with different physical and mechanical properties. The common types of mining surface failure in loess hilly mining areas are cracks, landslides, collapse pits, and caving, as shown in Fig. 5. Among these failure types, fracture is the most common. The type of failure is affected by the strata, topography, loess properties, mining conditions, and other factors. This study mainly analyzes the classification, formation mechanism, and influencing factors of mining-related fractures.
Figure 6 shows the classification process for surface cracks formed in coal-mining areas. The steps of this process are detailed as follows.

(1) The crack is classified as a dynamic crack or permanent crack according to the timeframe of crack development. Dynamic surface cracks are mainly distributed directly above the coal face with the fracture direction perpendicular to the driving direction of the working face. The spacing of cracks is related to the periodic pressure of the roof of the working face. Some dynamic cracks will be closed or reduced as the working face advances. Permanent cracks are mainly distributed above the working face boundary, and their sizes and shapes tend to be stable after mining stops. Fracture development can be divided into four stages: the continuous deformation stage (early stage of mining); the generation and slow development stage; the intense development stage; and the stable fracture stage.

(2) According to the crack characteristics, cracks are divided into tensile cracks and step cracks. In loess hilly mining areas, both tensile and step cracks will form. Faces with relatively large ratios of mining depth to mining thickness will develop mostly tensile cracks, while step cracks will form under conditions of thick soil with thin bedrock.

(3) According to the formation mechanism, the cracks are divided into horizontal tensile fractures and vertical shear fractures. The change in overburden structure resulting from mining causes horizontal tension on the surface, while vertical shear occurs due to the movement of overburden in the vertical direction.

The above three classification methods are related to each other.

Horizontal stretching is the main reason for the formation of tensile cracks, while vertical shear is the main reason for the formation of step cracks. When horizontal tension and vertical shear coexist, the formed cracks exhibit both crack width and step height, the sizes of which are proportional to the magnitudes of the horizontal tension and vertical shear, respectively.

Another classification system divides the surface cracks caused by coal mining into four types: tensile, extrusion, collapse, crack, and sliding cracks. Extrusion cracks mostly occur in valley areas, while sliding cracks are primarily found on slopes covered by loess. The main factors controlling fracture development in coal mine goaf are bedrock thickness, loess overburden thickness, mining height, gully cutting topography (especially in mining areas with thick soil, thin bedrock, and large mining thickness), and slope. 


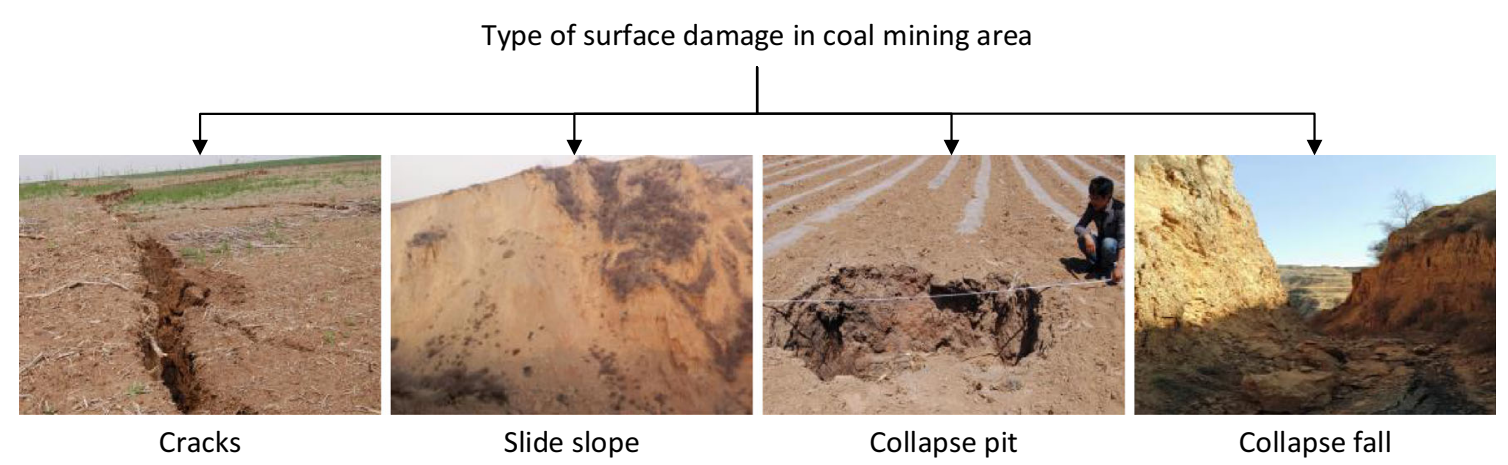

Fig. 5 Types of surface damage in coal-mining areas

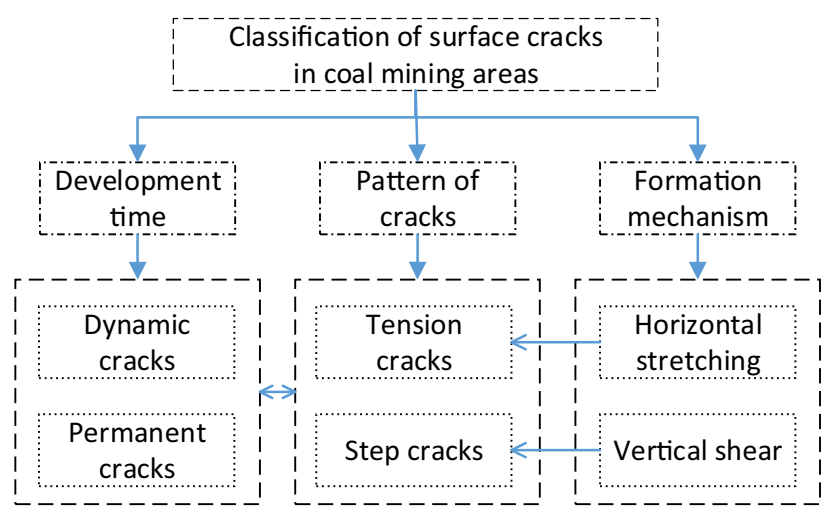

Fig. 6 Classification of surface cracks in coal-mining areas

In general, the effect of topography and loess on the surface subsidence rate is the subsidence rate of surface movement and deformation caused by coal mining in the plain area, which is less than 1 . The subsidence rate of GD3 is 1.18 (Table 1); this is mainly related to the sliding of the loess slope caused by mining, resulting in subsidence. The mechanism and calculation of surface slip in mountain mining have been discussed in detail (He and Kang 1992). The findings show that the topography and loess aggravate the movement of the mining surface, thereby worsening damage to the ground.

\section{Conclusions}

Underground coal mining causes the destruction of surface land. Through a detailed investigation of ground cracks in 13 mines of six major coal fields in Shanxi Province, China, the main factors influencing ground surface damage were evaluated. Based on the analysis of investigation results, the conclusions can be summarized as follows.

(1) Three conditions affect the occurrence of ground damage due to mining. (a) Material conditions: Given that loess is softer than bedrock, it is easily affected by mining. Thus, loess must account for a certain proportion of the mining depth for serious ground damage to occur. (b) Mechanical conditions: The overlying strata form a certain equilibrium structure. When the thickness of the rock is relatively small, equilibrium failure causes the overlying rock to move more violently than when the rock thickness is greater. (c) Geometric conditions: Higher ground slope tends to result in more ground damage. However, when the proportion of sandstone in the overburden is large, the degree of surface damage will be reduced, even if the above three conditions are conducive to serious damage.

(2) Mining under a thick loess layer and a thin bedrock layer is typical because the overlying bedrock is thinner, and the physical and mechanical properties of loess are different from that of bedrock, resulting in the severe destruction of bedrock and the transfer of bedrock to the loess surface, such as GD10. These geological and mining conditions should be further studied.

(3) The ground slope aggravates the degree of surface movement, primarily the sliding of the mountain body caused by the slope. In some mining areas, the ground subsidence is larger than the thickness of the extracted coal seam.

Acknowledgements This study was supported by the National Natural Science Foundation of China (Grant Nos. 51704205 and 51574132), Shanxi Natural Science Foundation of China (Grant No. 201701D221025) and Key R\&D Plan projects in Shanxi Province of China (Grant No. 201803D31044). We thank the reviewers for their helpful comments, Mr. Shengyun Chen, Mr. Xiaohua Wang, and Ms. Boting Guo for their hard work in data collection, and Dr. Zhang Sumei and Mr. Zoujun Li for their help with graphics.

Open Access This article is licensed under a Creative Commons Attribution 4.0 International License, which permits use, sharing, adaptation, distribution and reproduction in any medium or format, as long as you give appropriate credit to the original author(s) and the source, provide a link to the Creative Commons licence, and indicate if changes were made. The images or other third party material in this article are included in the article's Creative Commons licence, unless 
indicated otherwise in a credit line to the material. If material is not included in the article's Creative Commons licence and your intended use is not permitted by statutory regulation or exceeds the permitted use, you will need to obtain permission directly from the copyright holder. To view a copy of this licence, visit http://creativecommons. org/licenses/by/4.0/.

\section{References}

Adams SM, Friedland CJ (2011) A survey of unmanned aerial vehicle (UAV) usage for imagery collection in disaster research and management. In: 9th International Workshop on remote sensing for disaster response, 2011

Chengsheng Y, Zhang Q, Chaoying Z, Lingyun J, Wu Z (2010) Monitoring mine collapse by D-InSAR. Min Sc Technol 20:696-700

Cui X, Gao Y, Yuan D (2014) Sudden surface collapse disasters caused by shallow partial mining in Datong coalfield, China. Nat Hazards 74:911-929

Dong S, Yin H, Yao S, Zhang F (2013) Detecting surface subsidence in coal mining area based on DInSAR technique. J Earth Sci 24:449-456

Du Z, Ge L, Ng AH-M, Li X (2018) Investigation on mining subsidence over Appin-West Cliff Colliery using time-series SAR interferometry. Int J Remote Sens 29:1528-1547

Erdelj M, Król M, Natalizio E (2017) Wireless sensor networks and multi-UAV systems for natural disaster management. Comput Netw 124:72-86

Graniczny M, Colombo D, Kowalski Z, Przyłucka M, Zdanowski A (2015) New results on ground deformation in the Upper Silesian Coal Basin (southern Poland) obtained during the DORIS Project (EU-FP 7). Pure Appl Geophys 172:3029-3042

Grzovic M, Ghulam A (2015) Evaluation of land subsidence from underground coal mining using TimeSAR (SBAS and PSI) in Springfield, Illinois, USA. Nat Hazards 79:1739-1751

He W, Kang J (1992) Laws of ground movement and deformation in mountainous areas (in Chinese). J China Coal Soc 17:1-15

Huang J, Deng K, Fan H, Yan S (2016) An improved pixel-tracking method for monitoring mining subsidence. Remote Sens Lett 7:731-740

Ishwar S, Kumar D (2017) Application of DInSAR in mine surface subsidence monitoring and prediction. Curr Sci 112:46-51

Iwasaki A, Miyatani S, Nakasuka S (2012) Satellite contributions to disaster monitoring-japanese earthquake and tsunami case in 2011. Paper presented at the 26th Annual AIAA/USU Conference on Small Satellites, Utah, USA

Junjie C, Hua N, Weitao Y, Wenbing G, Youfeng Z (2016) Features of surface dynamic movement and deformation caused by high intensity mining with shallow depth. Coal Sci Technol 44:158-162

Kim S, Lee W, Park Y-S, Lee H-W, Lee Y-T (2016) Forest fire monitoring system based on aerial image. In: 2016 3rd International Conference on Information and Communication Technologies for Disaster Management (ICT-DM), pp 1-6. IEEE

Kurz F, Meynberg O, Rosenbaum D, Türmer S, Reinartz P, Schroeder M (2012) Low-cost optical camera system for disaster monitoring. Int Arch Photogramm Remote Sens Spat Inf Sc 39:B8

Kussul N, Skakun S, Shelestov AY, Kussul O, Yailymov B (2014) Resilience aspects in the sensor Web infrastructure for natural disaster monitoring and risk assessment based on Earth observation data. IEEE J Sel Top Appl Earth Obs Remote Sens 7:3826-3832

Kwak Y-j (2017) Nationwide flood monitoring for disaster risk reduction using multiple satellite data. ISPRS Int J Geo Inf 6:203

Lian X, Dai H (2016) Mapping the degree of damage to houses of Paifang village, Anhui, China, caused by underground coal extraction. Environ Earth Sci 75:182

Lian X, Hu H (2017) Terrestrial laser scanning monitoring and spatial analysis of ground disaster in Gaoyang coal mine in Shanxi, China: a technical note. Environ Earth Sci 76:287

Lule E, Bulega TE (2015) A scalable wireless sensor network (WSN) based architecture for fire disaster monitoring in the developing world. Int J Computer Netw Inf Secur 7:40

Mirek K (2012) Satellite radar interferometry (InSAR) used for estimation of ground subsidence in mining areas-Upper Silesian Coal Basin Case Study. Pol J Environ Stud 21:312-316

Ng AH-M, Ge L, Yan Y, Li X, Chang H-C, Zhang K, Rizos C (2010) Mapping accumulated mine subsidence using small stack of SAR differential interferograms in the Southern coalfield of New South Wales, Australia. Eng Geol 115:1-15

Przyłucka M, Herrera G, Graniczny M, Colombo D, Béjar-Pizarro M (2015) Combination of conventional and advanced DInSAR to monitor very fast mining subsidence with TerraSAR-X data: bytom City (Poland). Remote Sens 7:5300-5328

Samsonov S, d'Oreye N, Smets B (2013) Ground deformation associated with post-mining activity at the French-German border revealed by novel InSAR time series method. Int J Appl Earth Obs 23:142-154

Shanxi Province Statistics Bureau (2014-2018) Shanxi Statistical Yearbook. China Statistical Publishing House, Shanxi, China

Singh G, Yamaguchi Y, Boerner W-M, Park S-E (2013) Monitoring of the March 11, 2011, off-Tohoku 9.0 earthquake with supertsunami disaster by implementing fully polarimetric highresolution POLSAR techniques. Proc IEEE 101:831-846

Taenaka S, Akiyama J, Fujiki T, Takayama S (2012) Design of flexible wireless sensing network system for landslide disaster monitoring. In: 2012 Proceedings of SICE annual conference (SICE), pp 1443-1447. IEEE

Wang F, Jiang B, Chen S, Ren M (2019) Surface collapse control under thick unconsolidated layers by backfilling strip mining in coal mines. Int J Rock Mech Min 113:268-277

Wegmuller U, Walter D, Spreckels V, Werner CL, Sensing R (2010) Nonuniform ground motion monitoring with TerraSAR-X persistent scatterer interferometry. IEEE Trans Geosci Remote Sens 48:895-904

Yan W, Dai H, Chen J (2018) Surface crack and sand inrush disaster induced by high-strength mining: example from the Shendong coal field. China Geosci J 22:347-357

Yuan C, Zhang Y, Liu Z (2015) A survey on technologies for automatic forest fire monitoring, detection, and fighting using unmanned aerial vehicles and remote sensing techniques. Can J For Res 45:783-792

Zhang K, Ng AH-M, Ge L, Dong Y (2010) Multi-path PALSAR interferometric observations of the 2008 magnitude 8.0 Wenchuan earthquake. Int J Remote Sens 31:3449-3463

Zhang Z, Wang C, Tang Y, Zhang H, Fu Q (2015) Analysis of ground subsidence at a coal-mining area in Huainan using time-series InSAR. Int J Remote Sens 36:5790-5810

Zhao C, Lu Z, Zhang Q (2013) Time-series deformation monitoring over mining regions with SAR intensity-based offset measurements. Remote Sens Lett 4:436-445 